\title{
Transcription Elongation Regulator 1-Like Protein
}

National Cancer Institute

\section{Source}

National Cancer Institute. Transcription Elongation Regulator 1-Like Protein. NCI

Thesaurus. Code C120565.

Transcription elong ation regulator 1-like protein (586 aa, $67 \mathrm{kDa}$ ) is encoded by the human TCERG1L gene. This protein may plays a role in the modulation of insulin activity. 